\title{
The Marvelous Clouds: Toward a Philosophy of Elemental Media
}

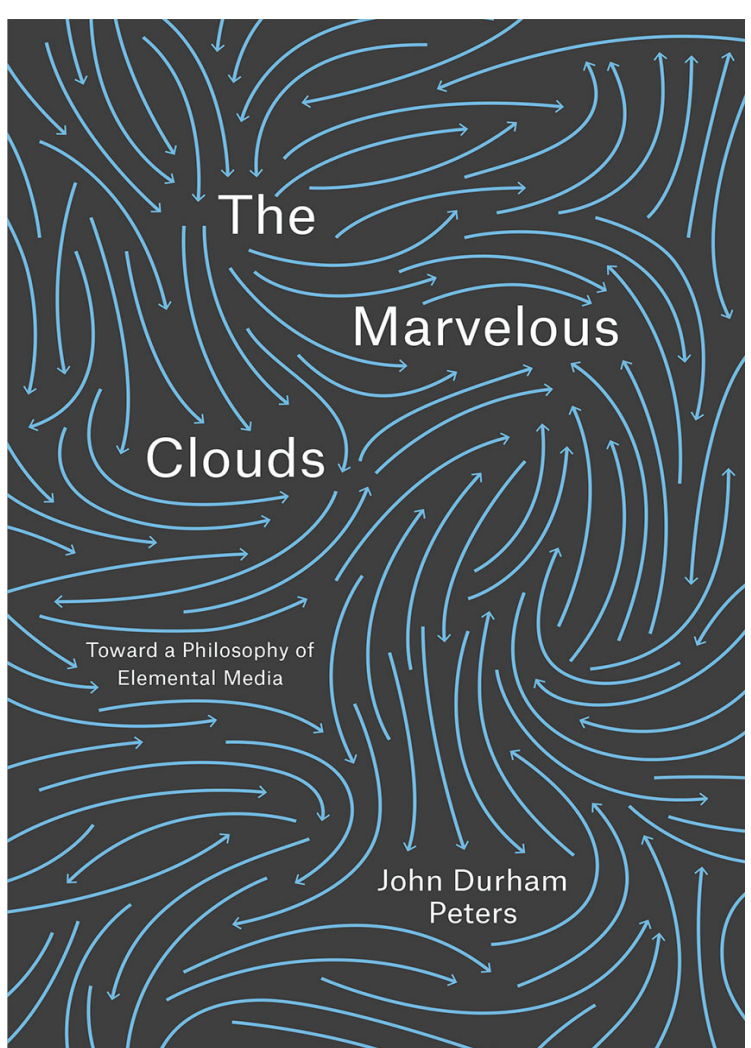

John Durham Peters

The Marvelous Clouds: Toward a Philosophy of Elemental Media

The University of Chicago Press, 2015, 410 pp., ca. € I8,- ISBN 9780226421353

'The idea that [clouds] could be media is a test of the limits of the concept.' (p. 254)

In the introduction to his latest book media historian and theorist John Durham Peters writes: 'Basics, contrary to the popular opinion, are not the easiest but the hardest part of any field of learning' (p. Io). The basic question of media studies - what are media? - lies at the heart of Peters' book and it takes a philosophical journey to answer it. Peters promises to provide nothing less than a "meditation of the human condition, which also means a meditation on the nonhuman condition' (p. I2). Fortunately, Peters is an experienced and skillful captain of the craft - his metaphor of choice for his book - that navigates the deep.

If we were to write histories of media, we would first need to understand what media are and what they do. Therefore, Peters strives to re-conceptualize the term media. However, before we can ask what media are we need to address what we mean by meaning. Meaning, in Peters' sense does not mean 'mental content intentionally designed to say something to someone,' but rather 'repositories of readable data and processes that sustain and enable existence' (p. 4). As a consequence, Peters starts from the premise that there is meaning in nature. This meaning we can 'read' with the 'civilizational ordering devices' and 'ensembles of natural element and human craft' we call media (p. 3-5).

Peters' treatment of the media concept is therefore inclusive. The danger of such an approach is that everything becomes media, and everything becomes the object of media studies. Not only does this provide teachers of media studies with a challenge - where would we begin explaining this to undergrads? - but media researchers will have to complement their disciplinary backgrounds and move their analytical lens toward biology, chemistry and (meta)physics, in other words, the science of life and matter instead of symbolic (media) content. 
'To study media', Peters argues, 'you cannot just study media' (p. 29). Consequently, we would be writing the history of everything else. Elementally, in Peters' view, media are things in the middle of things that affect other things. Indeed, 'medium has always meant an element, environment, or vehicle in the middle of things' (p. 46). Peters avoids talking about the matter of agency here; however, things in between, whatever they are, are activated, enacted, used, switched on, constructed and imagined. Peters, following actor-network-theory (ANT), would counter this: 'the agency of human beings is a question we should answer, not a fact we should assume' (p. 89).

Going back to basics means going back to infrastructure; in other words, media that stand under (hence the pun of the chapter title Understanding Media). To understand the ontology of media (their 'being') is to understand their infrastructure. 'Ontology', asserts Peters, 'is usually just forgotten infrastructure' (p. 38). Therefore, media historians should scrutinize the mundane, the taken for granted, and the boring. In other words, instead of focusing on recording media (which compress time) or transmitting media (which compress space), they should consider logistical media (which organize and arrange things and people). Examples of this include the study of calendars, clocks, towers, lists, and money. To this list we might add, after reading Peters, ships, clouds, fire and dolphins as well. Latour is fascinated by chimpanzees (and the work by Jane Goodall), Peters has a particular interest in dolphins and whales - he spends more than fifty pages on our 'briny cousins', as he affectionately calls them.

What do dolphins have to do with media theory and, more pertinently, media history? The answer lies, according to Peters, in the fact that dolphins have techniques but not technology.
Techniques are embodied practices, whereas technologies are durable externalizations. Even though they are highly intelligent, cetaceans 'can create with their bodies, but not with their hands. They show us by contrast how intertwined our being is with our material environment' (p. 79). Peters argues that there is nothing more human(e) than technology. Humans cannot exist, cannot be, without technology.

An insight from paleontologist LeroiGourhan that Peters likes to repeat is that ever since our species started to walk on two feet, our hands and brains evolved to the extent to which we could shape the world around us. In turn, that altered world started to reshape us. Following ANT, the human species is 'networked' from the beginning. We are embedded within networks of things, places, environments, and other people. Indeed, argues Peters, our very own bodies are 'technical systems as strange and mysterious as any devices we use' (p. 89). We are, in mind and matter, technological beings. Therefore, our bodies and DNA - our most fundamental media - are very much historical.

On a critical note, Peters seems to conflate the concepts of media and technology in his book. Media are technologies and technologies are media. This argument seems to be incongruent, though: when only humans are capable of technology, why does he push the idea that there are such things as 'natural media'? Is the sea a medium? Peters asks. It is not, if media are technologies, but it is to dolphins who use it as a vehicle for sonar and a means of transport. This constant stretching of the concept of the media might irritate the reader who is looking for clear answers. However, his love for knowing and knowledge sparks off the pages. This is exactly his goal: to provide sparks through scholarly rigor. 
Peters' book is one of those works that is endlessly quotable. His writing contains both quirks and quips and he loves to indulge in (sometimes showy) etymological tangents (Peters commands a number of languages besides English). He also does not shun sharp critique, grand statements, esoteric observations, and timely warnings. Readers are guided from Ancient Greek mythology to Google and from the anatomy of dolphins to the philosophy and politics of Heidegger. Peters connects ideas from literature (especially Emerson) to those of the natural sciences and anthropology. Hence, he takes his readers on a philosophical journey that ignores the 'two cultures' of natural and humanist sciences (C.P. Snow would praise this book). Peters seems to argue, through his erudition and allusive language, that a true historian and philosopher of media would be a world-traveler, knowing about physis and technē.

Invisible infrastructures and processes become visible when they fail, break down, or stop working. This insight - mainly from science and technology studies - is one of Peters' central arguments and matters of concern, as Latour would call it. The Thing that is failing, breaking down, and will stop working, ultimately, is the greatest infrastructure: Planet Earth and the millions of species inhabiting it, including our own. Tragically, we are the harbingers of our own demise, since we started to domesticate our natural environments and in the process became thoroughly dependent on it. This, of course, is not a new insight (cf. the work of Ian Hodder). What is new, however, is that Peters makes this demise the concern of media studies, by extending what we mean by media-which might include the marvelous clouds.

Rik Smit, Centre of Media and Journalism Studies, Rijksuniversiteit Groningen 